
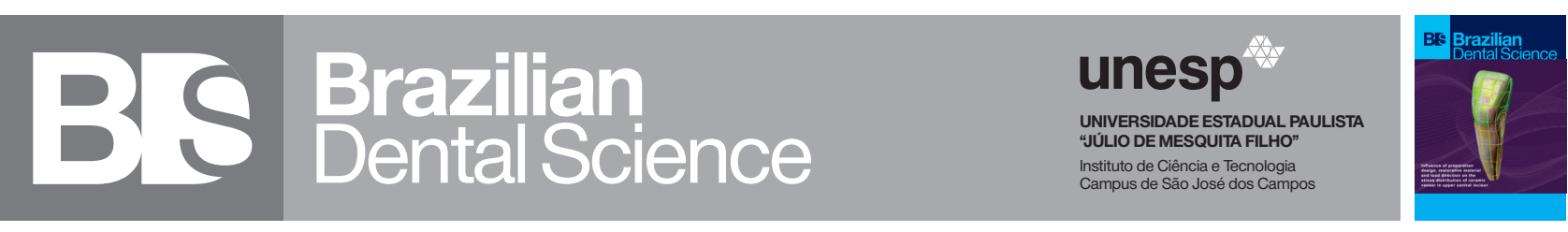

\title{
Patient Satisfaction and Pink Esthetics of PEEK Versus Zirconium Abutments in the Esthetic Zone (A Randomized Controlled Trial)
}

\author{
Satisfação do paciente e estética rosa dos pilares PEEK versus Zircônia na zona estética (um ensaio clínico randomizado)
}

\author{
Mostafa M EL-SHABRAWY ${ }^{1}$, Amina A ZAKI ${ }^{2}$, Jylan ELGUINDY ${ }^{3}$, Hani El NAHASS ${ }^{4}$, Karim Abou BAKR ${ }^{5}$ \\ 1- Assistant lecturer of Fixed Prosthodontics- Faculty of Oral and Dental Medicine- Egyptian Russian University-Cairo- Egypt. \\ 2 - Professor of Fixed Prosthodontics- Faculty of Dentistry- Cairo University and Head of Fixed Prosthodontics Department- Faculty of Oral \\ and Dental Medicine, Egyptian Russian University, Cairo- Egypt. \\ 3 - Professor of Fixed Prosthodontics- Faculty of Dentistry- Cairo University and Vice Dean for Education and Students Affairs- Nahda \\ University- Cairo- Egypt. \\ 4 - Associate Professor of Periodontology, Faculty of Dentistry- Cairo University - Cairo - Egypt. \\ 5 - Lecturer of Fixed Prosthodontics- Faculty of Dentistry- Cairo University.
}

\section{ABSTRACT}

Objective: This study was performed to evaluate the use of PEEK abutments versus zirconium abutments with lithium disilicate superstructure on the esthetic acceptance and peri-implant clinical parameters. Zirconium abutments were found to have high surface roughness even after polishing. This causes a remarkable collapse of the soft tissue papilla that is a primary factor in the Pink Esthetic Score(PES), resulting in failed esthetic restoration in the anterior esthetic zone. Material and Methods: Twenty patients who needed a single implant restoration in the esthetic zone were included in this study. Eighteen patients completed screening, baseline, three-month, six-month, and twelve-month follow-up visits. At the screening visit, the patients were randomly allocated into two groups: Zirconia abutments (A) Group, and PEEK abutments (B) Group, both of which were restored with IPS e.max CAD superstructure. Patients Satisfaction was assessed by visual analogue scale (VAS). Pink esthetics score (PES), modified plaque index (mPI) and modified gingval index (mGI) were also assessed. Results: All implants were successfully osseo-integrated with a 100\% survival rate over one year. Patient satisfaction was significantly higher for the PEEK group than the zirconium group. The pink esthetic

\section{RESUMO}

Objetivo: Este estudo foi realizado para avaliar o uso de pilares PEEK versus pilares de zircônia com estrutura de dissilicato de lítio quanto a aceitação estética e parâmetros clínicos periimplantares. Os pilares de zircônia apresentam alta rugosidade superficial, mesmo após o polimento. Isso causa um colapso notável da papila do tecido mole, que é um fator primário no índice estético rosa (Pink Esthetic Score - PES), resultando em falha na restauração estética na zona estética anterior. Materiais e Métodos: Vinte pacientes que precisavam de um implante unitário na zona estética foram incluídos neste estudo. Dezoito pacientes completaram a triagem, a consulta inicial e as visitas de acompanhamento de três, seis e doze meses. Durante a triagem, os pacientes foram aleatoriamente divididos em dois grupos: Grupo Pilares de Zircônia (A) e Grupo de Pilares PEEK (B), ambos foram restaurados com IPS e.max CAD. A satisfação dos pacientes foi avaliada pela escala visual analógica (VAS). $\mathrm{O}$ PES, o índice de placa modificado (mPI) e o índice gengival modificado (mGI) também foram avaliados. Resultados: Todos os implantes foram osseointegrados com sucesso, com uma taxa de sobrevivência de $100 \%$ ao longo de um ano. A satisfação do paciente foi significativamente maior para o grupo PEEK quando comparado com o grupo de pilares de zircônia. O índice 
score showed no statistical significance between both groups. The modified plaque index was significantly lower for the PEEK group than the zirconium group. The modified gingival index showed no statistical difference between both groups. Conclusion: PEEK revealed to be a versatile material to replace zirconium for implant abutments, due to its lower plaque affinity and higher patient satisfaction.

\section{KEYWORDS}

Dental implantation; Patient satisfaction; PEEK abutments; Pink esthetic score (PES); Zirconium abutments. da estética rosa não apresentou significância estatística entre os dois grupos. O índice de placa modificado foi significativamente menor para o grupo PEEK quando comparado com o grupo de pilares de zircônia. Conclusão: O PEEK revelouse um material versátil para substituir a zircônia em pilares de implante, devido a sua menor afinidade de placa e maior satisfação do paciente.

\section{PALAVRAS-CHAVE}

Implantação dentária; Satisfação do paciente; Pilares PEEK; Índice Estética Rosa; Pilares de zircônia.

\section{INTRODUCTION}

$\mathrm{D}$ ental implants have been used for restoration of missing teeth [1]. A lot of innovations were done to gain an optimum level in the predictability of the Osseo-integration of the dental implant with bone. After reaching great levels of bone to implant contact, research started to grow and focus more towards the esthetics of dental implants prostheses [2]. Zirconium abutments have been used on implants used in the esthetic zone due to their white appearance [3]. On the other hand, recent reports addressed the high surface roughness of zirconia that in turn increases bacterial adhesion, therefore, causing peri-implantitis and affecting the survival rate of the whole dental structure [4]. The introduction of Polyetheretherketone (PEEK) seems to offer a smoother abutment while maintaining a more smoother surface than zirconium abutments.

The increase in life expectancy and age range caused an escalation on the demand of implants for edentulous patients for edentulous patients to about $26 \%$ about $44 \%$ at ages of 65 and above 75 years respectively [5]. After tooth loss, the surrounding bone starts to atrophy due to lack of use [6]. With a $90 \%$ success rate, dental implants proved to be a reliable prosthetic option [7]. Moreover the success rate for dental implants in the esthetic zone are similar to those implants placed at other places in the jaw [8].

Dental Implant's success is no longer only dependent on being functionally stable especially in the esthetic zone where the placement of dental implants is very challenging. Patient satisfaction and acceptance is of prime importance for the success of dental implants as well. Creating a proper illusion that the tooth is in harmony with the rest of the natural remaining dentition is one of the optimum goals for ideal dental implant treatment $[3,9,10]$.

Therefore, proper pink esthetics is a fundamental factor for gaining ideal esthetic outcome [11], for optimum patient satisfaction. The lack of metal shadow in zirconium abutments made them the standard of care in the esthetic zone. Besides they facilitate color matching of the superstructure with the adjacent natural dentition [12].

However, zirconium abutments were found to have high surface roughness even after polishing, which gives rise to viable bacterial adhesion and leads to peri-implantitis that causes bone resorption and subsequent gingival recession [6,13]. This causes a remarkable collapse of the soft tissue papilla that is a primary factor in the PES, resulting in failed esthetic restoration in the anterior esthetic zone.

Recently, the (PEEK) material was 
introduced to implant dentistry as a definitive prosthesis, after being just used as an interim restoration. PEEK material is highly biocompatible and its white color makes its usage in the esthetic zone extremely satisfactory [14]. This material exhibits a smoother surface after polishing, therefore gives less chance for microorganism adhesion, and development of peri-implantitis and hence provides better esthetics [4].

However, it is still unknown which material is better, regarding the patient satisfaction, esthetics and peri-implant tissue health. Hence, the objectives of this study are to explore the effect of PEEK versus Zirconium abutments on these outcomes, and to provide recommendation for the practitioners about the material that provides better esthetic longevity.

A successful dental implant in the esthetic zone is no longer dependent only on mechanical and biological aspects [15]. The esthetic outcome is of prime importance for the patient, producing a restoration duplicating the adjacent natural tooth is a very difficult task. Before the use of zirconium, titanium abutments used to have a see through appearance of their famous silver hue through the soft tissue [16]. Zirconium abutments counteracted this problem due to their white color mimicking natural tooth shade. Aside from this advantage also their biocompatibility plays a great role for choosing them as an esthetic abutment [17]. Recording lower levels of inflammatory responses than titanium abutments [18].

It was found worth to investigate the patient satisfaction, pink esthetic score and peri-implant clinical parameters of PEEK versus zirconium abutments in the esthetic zone. The null hypothesis for this study was that there would be no statistical difference between PEEK and zirconia in regards to patient satisfaction; pink esthetic score or peri-implant clinical parameters.

\section{MATERIALS AND METHODS}

\section{Ethical considerations and approval:}

This study was approved by the Research Ethics Committee of the Faculty of Dentistry, Cairo university, Cairo, Egypt (approval no: 1692). Written informed consent regarding treatment sequence, publishing of their images and results was obtained from all participants.

\section{Registration:}

This trial was registered at the pactr. org registry under registration number PACTR201608001726196 on August 11, 2016.

\section{Study Design}

This study was performed in the clinics of Fixed Prosthodontic Department Faculty of Dentistry, Cairo University, Cairo, Egypt. This study involved two groups of patients (10 Patients in each group). A total of twenty implants were included in this study and completed by one operator (the researcher) who followed a strict clinical procedure; the operator followed the five phases of Implant placement and loading: diagnosis, surgery, exposure, impression, try-in and cementation. All prosthesis were done by one experienced dental technician.

The materials investigated for this study are presented as brand names, composition and manufacturer in (Table I and II).

Table I - Materials names, composition, manufacturers and lot number for comparator and intervention

\begin{tabular}{|c|c|c|c|}
\hline Material Name & Composition & Manufacturer & $\begin{array}{l}\text { Lot } \\
\text { Number }\end{array}$ \\
\hline Katana Zirconia(ML) & $\begin{array}{c}\mathrm{ZrO} \mathrm{O}_{2}+\mathrm{HfO}_{2} 87-92 \% \text { Yttrium 0xide } \\
\left(\mathrm{Y}_{2} \mathrm{O}_{3}\right) \text { 8-11\% Other oxides } 0-2 \%\end{array}$ & $\begin{array}{l}\text { Noritake Dental Inc., } \\
\text { (Japan) }\end{array}$ & DJXSU \\
\hline breCAM. BioHPP & $\begin{array}{l}\text { Partly Crystalline Polyethere- } \\
\text { therketone (PEEK) that is streng- } \\
\text { thened using } 20 \% \text { ceramic fillers }\end{array}$ & $\begin{array}{l}\text { BredentGmbH\& } \\
\text { Co.KG (Germany) }\end{array}$ & 496211 \\
\hline IPS e.max CAD & 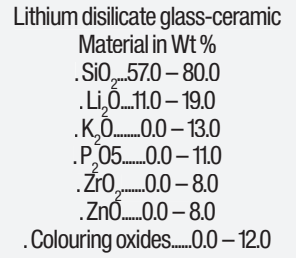 & $\begin{array}{l}\text { Ivoclar Vivadent } \\
\text { (Germany) }\end{array}$ & X37848 \\
\hline
\end{tabular}


Table II - Materials names, composition, manufacturers and lot number used in this study

\begin{tabular}{|c|c|c|}
\hline Material Name & Manufacturer & $\begin{array}{c}\text { Lot } \\
\text { Number }\end{array}$ \\
\hline ISII Active & Neobiotech, South Korea & F010119081103 \\
\hline Zhermack Elite & Zhermack, Italy & 339747 \\
\hline IS Scan Body & Neobiotech, South Korea & ISPSBH4ONB \\
\hline Titanium Link Abutment & Neobiotech, South Korea & ISLKN4035NB \\
\hline visio.link & Bredent, Senden Germany & 141442 \\
\hline Z-prime Plus & Bisco, USA & 1900006919 \\
\hline $\begin{array}{c}\text { Bisco, Porcelain Etchant } \\
(9.5 \%)\end{array}$ & Bisco, USA & 2000004800 \\
\hline Ceramic Primer & Bisco, USA & 1900006757 \\
\hline Biscem & Bisco, USA & 2000004834 \\
\hline OxyGuard Panavia F2.0 & $\begin{array}{l}\text { Kuraray Noritake Dental } \\
\text { Inc., Japan }\end{array}$ & $00675 A$ \\
\hline
\end{tabular}

\section{Recruitment}

All participants fulfilled the following inclusion criteria, patients above 18 years old, patients able to read and sign the informed consent document, medically free patient or with controlled systemic disease that was checked through past medical history part in the diagnostic chart. Bone quality D2 or D3, evaluated by CBCT to be with a minimum $6 \mathrm{~mm}$ bucco-lingual bone quantity. The missing tooth to be restored should be bounded by intact natural teeth; there should be a minimum of $2 \mathrm{~mm}$ of bone away from any vital structures, as well as cooperative patients.

The exclusion criteria were young patients in growth stage, patients with unsuitable implantation sites (patients with major bony defects Type 2 or Type 3 due to accidents or severe bone resorption), pregnant women, patients with uncontrolled systemic disease (hypertensive or uncontrolled diabetes mellitus) and psychiatric problems or unrealistic expectations.

The patients that fulfill the inclusion criteria were recruited during the time from August 2016 till September 2018 from the outpatient clinic of the fixed prosthodontics department - Cairo University. Screening of patients was carried out until target number was reached. This study was completed by January 2020. Full medical and dental history was obtained from all participants.

The reason of extraction was due to inability to restore a badly decayed tooth due to absence of ferrule effect or periodontal problem. Immediate extraction and implantation was to be performed to all the cases. All extractions were done atraumatically to preserve the buccal plate of bone for optimum post-operative esthetic outcome. A periodontist was responsible for all the surgical procedures, all implants were placed immediately after tooth extraction.

\section{Patient Selection}

A total of 20 patients (12 females, 8 males) were selected for the study with an age range between 20 to 62 years old. Each participant received one implant and its implant prosthesis in the esthetic zone. The Esthetic zone refers to any tooth that is visible during patient's maximum smile. A maximum smile could be acquire by making the patient say the Letter "E" in a prolonged manner. The chief complaint was to enhance their smile. Information was given to each patient regarding the alternative treatment options. The treatment plan was explained for each patient. Then, they agreed to sign the informed consent before proceeding to clinical work. They were all able and willing to maintain good oral hygiene measures.

\section{Randomization}

Patient were divided into two groups using (www.randomizer.org)

\section{Sequence generation}

The researcher allocated the participants in to two groups with $1: 1$ allocation ratio by using computerized Sequence generation. The numbers from 1 to 20 were randomly distributed in a two-column table by the aid of random.org. Table II.

\section{Allocation concealments}

Patients are numbered from 1-20 by an indispensible pen, each number on large white paper sheet. The sheets were folded eight times 
and saved inside opaque well-sealed envelope in which the inner content could not be seen by naked eyes.

\section{Implementation}

Patients recruited by the investigator were responsible for generating the allocation sequence and allocating the patients to the treatment groups.

\section{Blinding}

The researcher carried out the steps of abutment positioning, impressions, and other procedural steps. Only the statistician and the prosthodontic Assessor were blinded because of being unaware of the abutment material used.

\section{Informed Consent}

An informed patient consent was obtained from all patients who participated in the study under the supervision of ethics committee of Faculty of Dentistry, Cairo University.

\section{Sample Grouping}

The 20 patients were divided into 2 groups (10 patients each) (Table III).

Table III - Sample Grouping

\begin{tabular}{|ccc|}
\hline Control Group (A) & $\begin{array}{c}\text { Intervention Group } \\
\text { (B) }\end{array}$ & $\begin{array}{c}\text { Total Number of all } \\
\text { Implants }\end{array}$ \\
\hline $\begin{array}{c}\text { Zirconium Abutments } \\
\text { with IPS e.max CAD }\end{array}$ & $\begin{array}{c}\text { PEEK Abutments with IPS } \\
\text { e.max CAD Superstructu- } \\
\text { Superstructure }(n=10)\end{array}$ & $\begin{array}{c}(\mathrm{N}=20) \\
\text { re }(\mathrm{n}=10)\end{array}$ \\
\hline
\end{tabular}

\section{Diagnostic Phase}

- History: A thorough comprehensive medical history was recorded for each patient through an interview.

- Dental examination: Periodontal evaluation, symmetry of gingival level, oral hygiene, dental caries and parafunctional habits were assessed. TMJ evaluation was conducted and intra-oral examination revealed the presence of opposite occluding dentition in the area intended for implant placement and restoration.

- Cone Beam Computed Tomography
CBCT was taken to make sure that the case was indicated for extraction and the bone level wasn't contra-indicating the placement of an implant. A CBCT was done for all the patients to check and analyze the bone available for implant selection

- Photographs: Pre-operative photographs for each patient were taking using 1-5mm Nikon macro lens with a ring flash mounted on Nikon D3500 DSLR camera (Figure 1).

\section{Digital Planning on CBCT}

After reviewing the CBCT using the digital simulation software (OnDemand, Cybermed. Korea), the available crestal bone width and the bone height was evaluated and the proper implant size was selected (Figure 2,3).

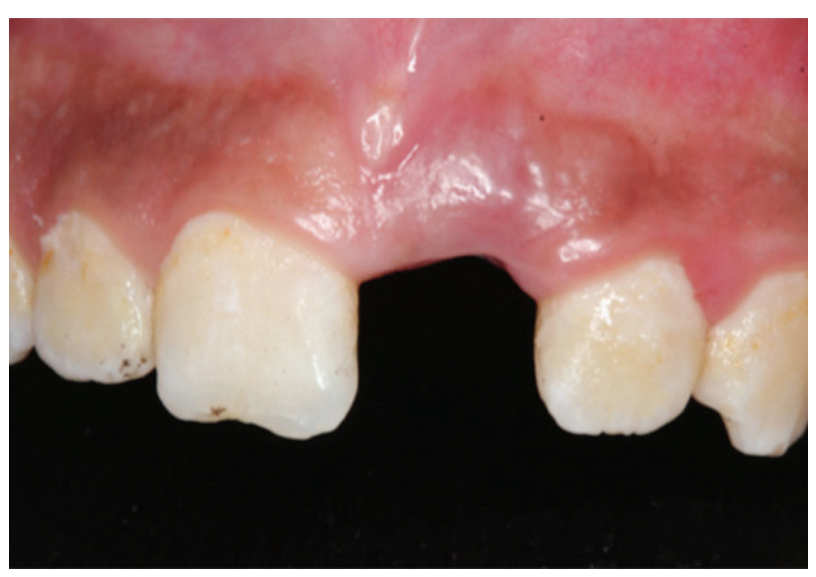

Figure 1- Pre-operative intra-oral view retracted with contraster.

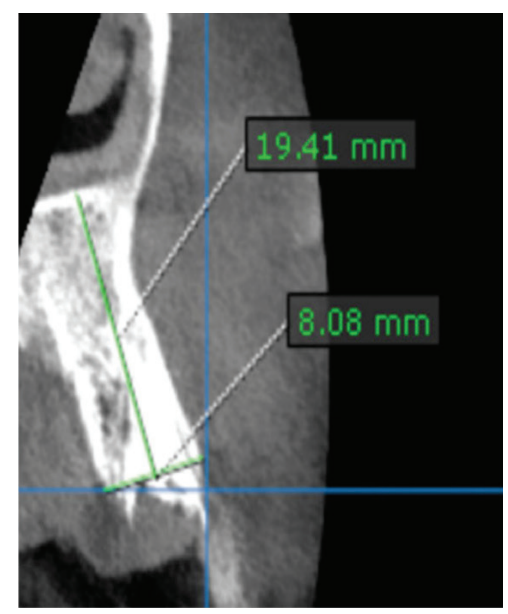

Figure 2 - Pre-operative CBCT sagittal cut. 


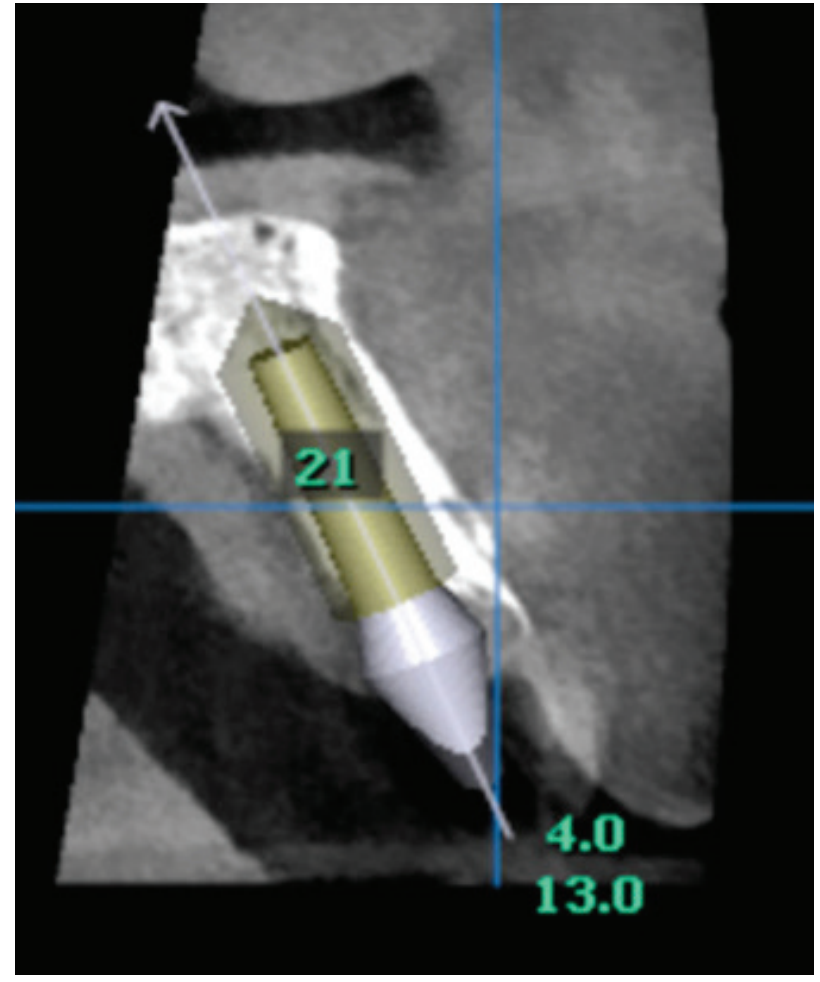

Figure 3 - Pre-operative digital implant simulation.

\section{Surgery}

Local anesthesia in which Septocaine (Articaine hydrochloride 4\% with 1:00000 Epinephrine, Septodont Corp. Canada) was administrated by buccal and palatal infiltration before the surgical procedure. The remaining root was deemed hopeless to be restored. Therefore a decision to extract and place an implant was therefore taken. A crestal incision was performed using a Scalpel and a \#15c blade (Henry Schein. USA) to expose the remaining root.

A periotome (Zepf Instruments. Germany) was used to severe the periodontal attachments between the root and the bone all sides around the root except for the labial surface for a performing atraumatic extraction (Figure 4 and 5).
An osteotomy probe (Zepf. Germany) was later used to palpate the socket to make sure that there is no dehiscence or fenestration of the buccal plate of bone. The extraction socket was then carefully curetted by a Lucas curette (Zepf. Germany) to remove any or granulation tissue to avoid any contamination with the proposed implant surface.

Osteotomy preparation was done $3-5 \mathrm{~mm}$ into the bone apical to the socket. The drilling was according to manufacturer's instructions the speed was 1,200 rpm and the torque was $35 \mathrm{~N}$ (Neobiotech IS II Active. South Korea) with copious saline irrigation. The pilot drill 2.2 $\mathrm{mm}$ in diameter was then used to drill through the apex of the osteotomy. The drill was then removed to check the angle and position of the drilling by removing the drill from the hand piece and placing it passively in the osteotomy. Drill sequence was then completed by using a $3.0 \mathrm{~mm}$ diameter drill, followed by $3.5 \mathrm{~mm}$ drill as the final drill (Figure 6 and 7).

The implant (Neobiotech IS II Active. South Korea) was then inserted by a hand ratchet into the osteotomy performed until the implant platform is flushed with the crestal bone. The implant was also placed slightly toward the palatal aspect to have at least 2 $\mathrm{mm}$ jumping distance and still be in proper prosthetic position. Regarding the mesiodistal position, the implant was placed at least 1.5 $\mathrm{mm}$ away from the adjacent teeth. A microgap of $1 \mathrm{~mm}$ was measured between the surface of the implant and the buccal bone, so xenograft bone (OneXeno Graft. Germany) was placed and condensed by bone condenser to close the microgap (Figure 8).

A Gelfoam (Collatape, Zimmer. USA) was then placed over the implant and the bone graft. The surgical site was sutured over for fixation of the Gelfoam.

After one week the patient was recalled for a check up and suture removal. 


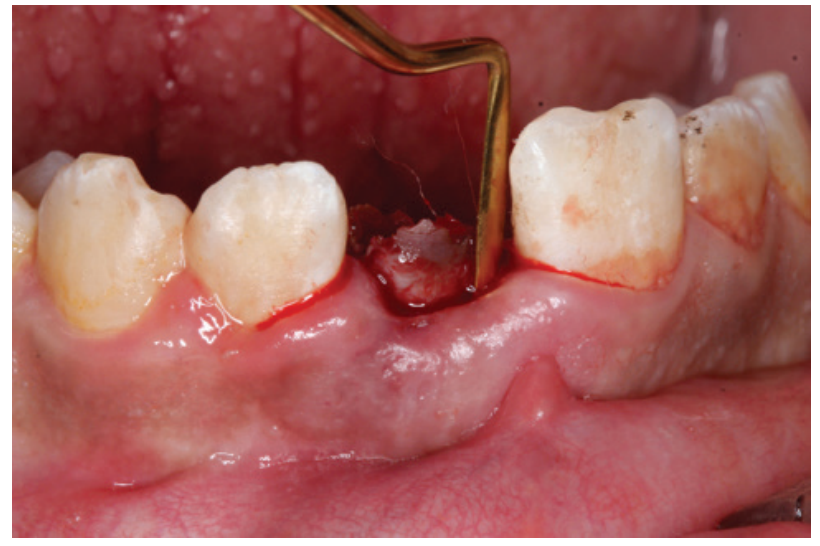

Figure 4 - Periotome for atraumatic extraction.

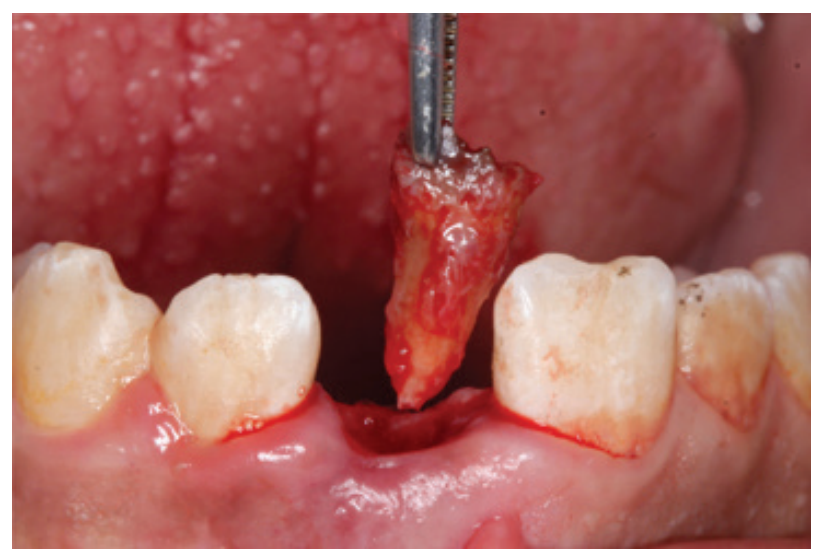

Figure 5 - Complete root extraction.

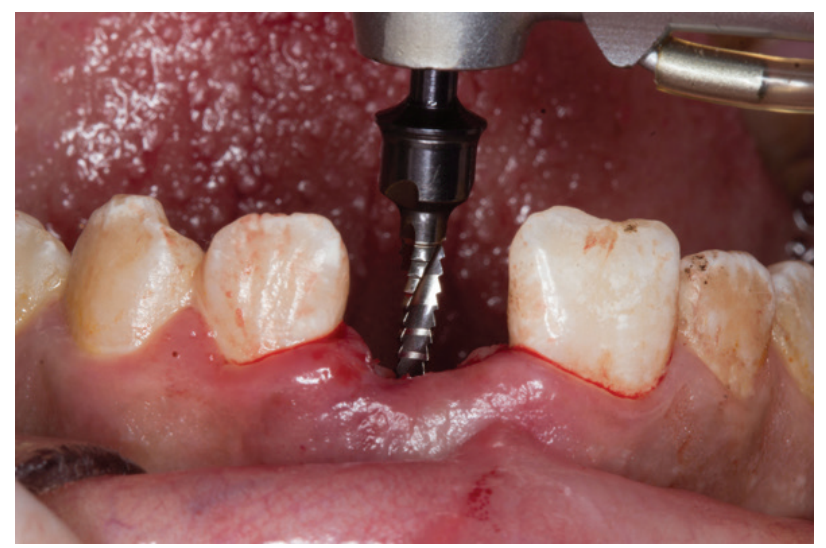

Figure 6 - Sequential drilling for implant placement.

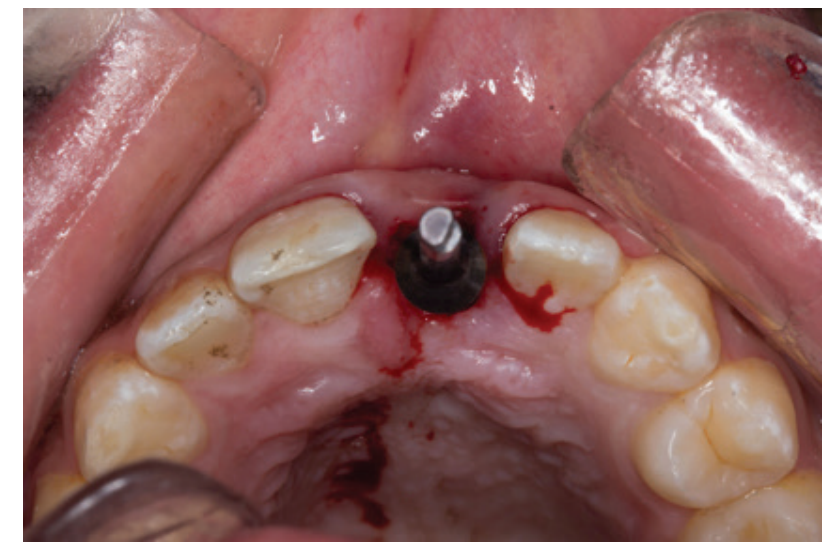

Figure 7 - Checking drilling position with adjacent teeth.

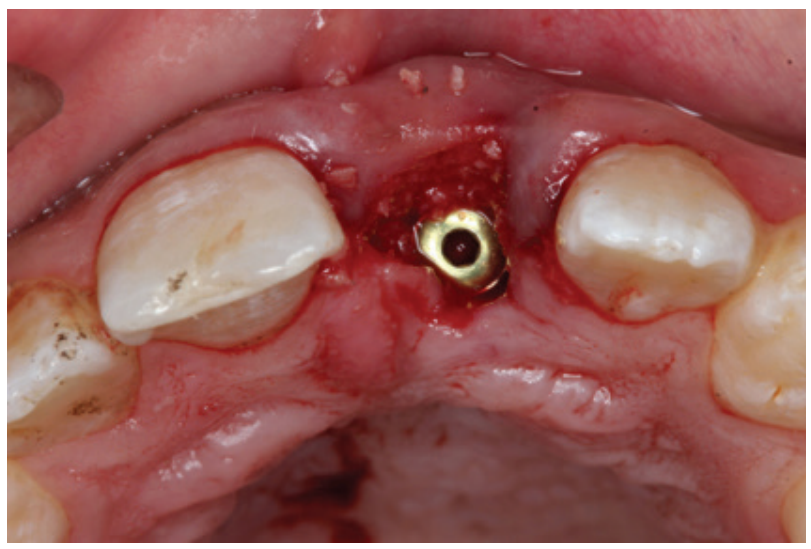

Figure 8 - Occlusal view after xenograft placement in buccal gap.

\section{Implant Exposure}

Three months later the patient was recalled for a peri-apical radiograph and surgical exposure with the $\mathrm{M}$ flap exposure technique to increase keratinized tissue buccally for better peri-implant results. An intra-sulcular incision was performed around the proximal aspects of the adjacent teeth, which extended slightly toward the palatal aspect. Then a horizontal slight palatal M-Shape incision connected the vertical incisions.

A customized healing collar was then fabricated for better tissue molding to transform the circular cross section to a more natural emergence profile mimicking the emergence profile of a central incisor (Figure 9). 


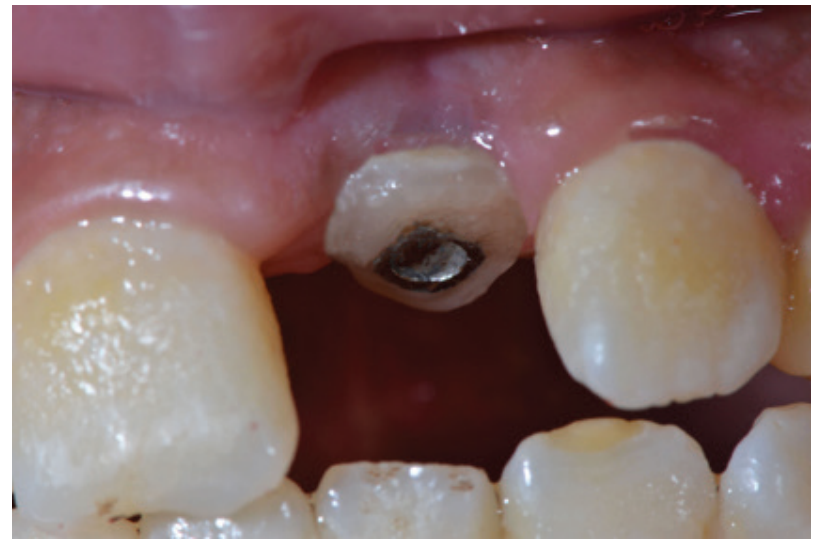

Figure 9 - Custom-made healing collar.

\section{Fabrication \\ Impression Making and Master Cast}

After one month of placement of the customized healing collar a soft tissue impression was then performed by transferring the molded soft tissue architecture from the customized healing collar to the transfer coping. The customized impression coping was utilized to transfer the actual soft tissue structure created to the stone cast for better emergence profile reproduction in the final restoration. The customized transfer coping was then attached to the implant and an open tray impression by the use of a customized special tray was taken with addition silicone putty (Zhermack Elite. Italy) and light consistency.

A soft tissue mask silicone (Multisil, Bredent. Germany) was injected inside the impression before stone (GC Fuji Rock, GC Corporation. Germany) pouring to reproduce the peri-implant attached molded intra-orally. A master cast was then produced.

\section{Scanning and Designing}

The poured master model was scanned using of an extra-oral scanner (Medit T300, Korea). The acquired STL file was opened on the CAD software Exocad 2018 (ExoCAD, Dental CAD. USA). An extra-oral scan body was fixed to the ti-base and scanned, a PEEK or Zirconia abutment was designed and milled.
The height of the abutment was performed to resemble an anatomically prepared tooth with a $2 \mathrm{~mm}$ occlusal clearance from any opposing dentition. The diameter of the abutments was designed to facilitate proper proximal contact after final restoration insertion. The emergence profile was designed following the soft tissue architecture produced on the master model. A collared anatomic shoulder finish line was milled on the abutment. A screw channel was made in the abutment with a minimum thickness of 2 $\mathrm{mm}$.

The milling condition was dry milling for Zirconia and PEEK abutments. The milling unit used for milling both materials was VHF CAM 5-S1. Post milling finishing for zirconia abutments started by cutting off and smoothening the sprue area, followed by ultrasonic cleaning. Drying of the zirconia abutments and then sintering for 6 hours for single abutments. As for the PEEK abutments the milled abutment only needed to cut the sprue and the abutment was ready.

\section{Abutment Try-in}

The milled PEEK or Zirconia abutment was then tried on the ti-base for proper margin placement. Adjustments were then performed and the abutment was scanned once more (Figure 10).

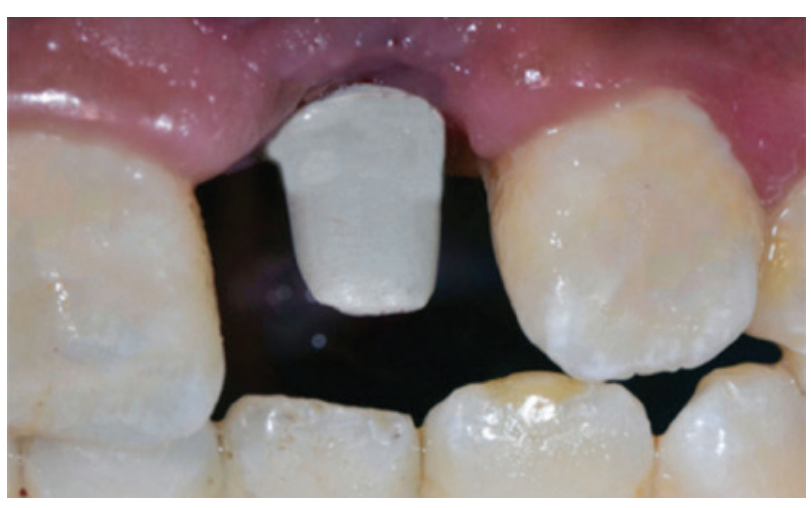

Figure 10 - PEEK abutment try-in. 


\section{Abutment Surface Treatment}

Preparation for PEEK abutments were done by applying a thin, uniform layer of Visio. link (Bredent. Germany) and cure in a light curing device for 90 seconds. On the other hand preparation for Zirconium abutments were performed by applying 2 coasts of Z-Prime Plus (Bisco. USA), then dry the surface with air syringe for 5 seconds.

\section{Superstructure Surface Treatment}

After proximal and occlusal contact adjustment the final Emax superstructure was then etched by $9.5 \%$ buffered hydrofluoric acid gel (Bisco. USA) and primed by the use of silane coupling agent (Ceramic Primer, Bisco. USA). A piece of Teflon was used to cover the abutment screw. The crown was then loaded with selfadhesive resin cement (BisCem, Bisco. USA) and placed on top of the PEEK or Zirconium abutment. Tack cure (Elipar S-10, 3M ESPE. USA) was performed then all the excess cement was removed by the use of scaler buccal and palatal, floss in the interproximal areas. Oxyguard (Oxyguard Panavia F 2.0, Kuraray. Japan) was placed over the margins circumferentially and then a full light cure cycle was then perfomed buccally and Palatally.

Post-operative photos were taken to be a baseline record for future assessment (Figure 11).

\section{Post-operative instruction and care:}

All patients were instructed to perform brushing and flossing regularly, using nonabrasive fluoridated toothpaste.

\section{Data Collection Methods:}

- Recall examinations were performed to all patients after 3, 6, 9, and 12 months. During the examination, evaluation of patients' satisfaction of the two groups assessed using the Visual Analog scale (VAS), which is binary and documented in chart including number of satisfied and unsatisfied and four questions (Figure 12).

- Pink Esthetic Score (PES) was evaluated by the criteria stated in (Table IV) along with the peri-implant clinical parameters.

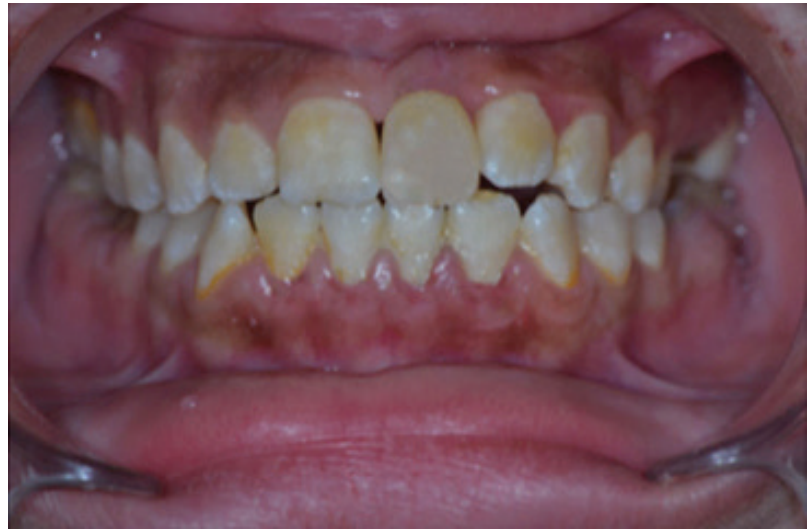

Figure 11 - Post-operative intra-oral view with retractor.

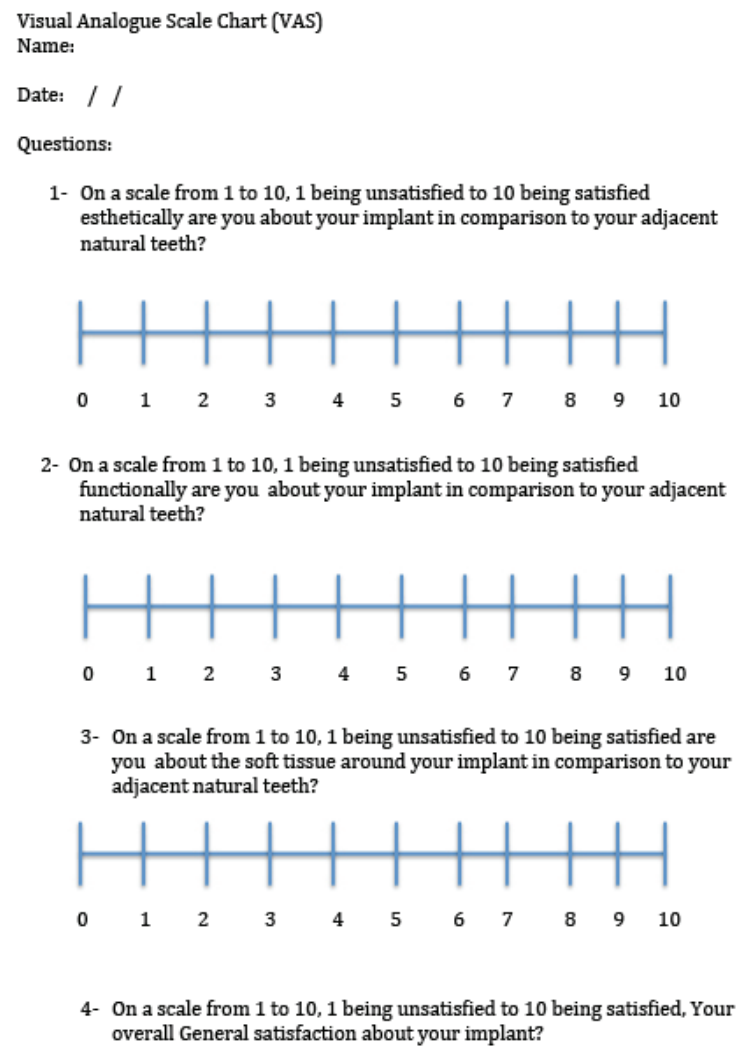
esthetically are you about your implant in comparison to your adjacent natural teeth?

2- On a scale from 1 to 10,1 being unsatisfied to 10 being satisfied functionally are you about your implant in comparison to your adjacent natural teeth?

4- On a scale from 1 to 10,1 being unsatisfied to 10 being satisfied, Your overall General satisfaction about your implant?

Figure 12 - Visual Analogue Scale (VAS). 
Table IV - The different outcomes and their measuring device and measuring unit

\begin{tabular}{|c|c|c|}
\hline Outcome & Scale & Measuring Unit \\
\hline Primary Outcome & $\begin{array}{l}\text { Patient Satis- } \\
\text { faction }\end{array}$ & Visual Analogue Scale (VAS) \\
\hline $\begin{array}{l}\text { Secondary Out- } \\
\text { come }\end{array}$ & $\begin{array}{l}\text { Pink Esthetic } \\
\text { Score }\end{array}$ & $\begin{array}{l}\text { 1. Presence of Mesial Papilla } \\
\text { 2. Presence of Distal Papilla } \\
\text { 3. Level of Soft tissue margin } \\
\text { 4. Soft tissue contour } \\
\text { 5. Alveolar Process } \\
\text { 6. Soft tissue color } \\
\text { 7. Soft tissue texture }\end{array}$ \\
\hline \multirow{2}{*}{$\begin{array}{l}\text { Tertiary Outcome } \\
\text { (Peri-implant Clinical } \\
\text { Parameters) }\end{array}$} & $\begin{array}{l}\text { Modified Plaque } \\
\text { Index (mPl) }\end{array}$ & $\begin{array}{l}\text { 0- No Detection of plaque. } \\
\text { 1- Plaque only recognized by running } \\
\text { a probe across the smooth marginal } \\
\text { surface of the implant. } \\
\text { 2- Plaque can be seen by the naked } \\
\text { eye. } \\
\text { 3- Abundance of soft matter }\end{array}$ \\
\hline & $\begin{array}{l}\text { Modified Gingival } \\
\text { Index (mGl) }\end{array}$ & $\begin{array}{l}\text { 0- No bleeding when a periodontal } \\
\text { probe is passed along the mucosal } \\
\text { margin adjacent to the tooth. } \\
\text { 1- Isolated bleeding spots visible. } \\
\text { 2- Blood forms a confluent red line on } \\
\text { mucosal margin. } \\
\text { 3- Heavy or profuse bleeding. }\end{array}$ \\
\hline
\end{tabular}

All the previous steps were repeated to the rest of the cases.

\section{RESULTS}

The value of the Kolmogorov-Smirnov Test of Normality (K-S) statistic (D) is 0.1957. The $p$-value is 0.4284 . The data does not differ significantly from that which is normally distributed.

Microstat7 for windows statistical package (Microstat Co) was used for statistical analysis in this study. One-Way ANOVA was used to compare between time intervals in each group followed by calculating Least Significant Difference (LSD) for paired comparisons between each interval in the same group. Independent Student " $\mathrm{t}$ " test was used to compare both groups in each interval. Difference was considered statistically significant when $\mathrm{p}<0.05$

\section{Patient Satisfaction (VAS):}

1. Comparison between groups for all questions:

Results of comparison between the two groups are presented in (Table V). Overall patient satisfaction in "PEEK" group was statistically significantly higher then in "Zirconium" group.
Table V - Independent student " $\mathrm{t}$ " test comparing patient satisfaction in both groups

\begin{tabular}{|ccccccc|}
\multicolumn{2}{c}{ Zirconium } & \multicolumn{2}{c}{ PEEK } & \multirow{2}{*}{ "t" } & Probability \\
Mean & StDev & Mean & StDev & & \\
\hline 8.58 & 0.92 & 9.64 & 0.45 & 3.092 & $0.003^{*}$ \\
\hline
\end{tabular}

2. Comparison between groups for each question:

Results of comparison between groups for each question are presented in (Table VI). In all 4 questions, the patient satisfaction scores in "PEEK" group was statistically higher than in the "Zirconium" group.

Table VI - independent student "t" test comparing mean values of patient satisfaction in both groups

\begin{tabular}{|c|c|c|c|c|c|c|}
\hline & \multicolumn{2}{|c|}{ Zirconium } & \multicolumn{2}{|c|}{ PEEK } & \multirow{2}{*}{$\mathbf{t}$} & \multirow{2}{*}{ Probability } \\
\hline & Mean & StDev & Mean & StDev & & \\
\hline Q1 & 8.67 & 1.12 & 9.56 & 0.73 & 2.000 & $0.031^{\star}$ \\
\hline Q2 & 8.78 & 0.97 & 9.67 & 0.50 & 2.440 & $0.013^{*}$ \\
\hline Q3 & 8.11 & 1.62 & 9.67 & 0.71 & 2.646 & $0.009^{*}$ \\
\hline Q4 & 8.78 & 1.09 & 9.67 & 0.50 & 2.219 & $0.021^{*}$ \\
\hline
\end{tabular}

\section{Pink Esthetic Score (PES)}

Comparison between groups

Results of comparison between groups for the PES are presented in (Table VII). There was no statistically significant difference of PES between both groups.

Table VII - Independent student " $\mathrm{t}$ " test comparing PES in both groups

\begin{tabular}{ccccccc}
\multicolumn{2}{c}{ Zirconium } & \multicolumn{3}{c}{ PEEK } & \multirow{2}{*}{ t } & Probability \\
Mean & StDev & Mean & StDev & & \\
\hline 8.56 & 2.96 & 9.78 & 2.59 & 0.932 & 0.183 \\
\hline
\end{tabular}

\section{Peri-implant clinical parameters}

\section{A. Plaque Index (mPI)}

1. Comparison between groups:

Results of comparison between groups are presented in (Table VIII), At baseline and after 
3 months, there was no statistically significant difference between both groups.

While the plaque index was significantly lower in "PEEK" group than in "Zirconium" group after 6, 9 and 12 months.

Table VIII - One-way ANOVA comparing mean values of plaque index during the follow up period in both groups and independent student " $\mathrm{t}$ " test comparing both groups in each interval

\begin{tabular}{|c|c|c|c|c|c|c|}
\hline \multirow{2}{*}{$\begin{array}{l}\text { Plaque } \\
\text { Index }\end{array}$} & \multicolumn{2}{|c|}{ Zirconium } & \multicolumn{2}{|c|}{ PEEK } & \multirow{2}{*}{ "t" } & \multirow{2}{*}{ Probability } \\
\hline & Mean & St Dev & Mean & StDev & & \\
\hline Baseline & 0.00 & 0.00 & 0.00 & 0.00 & 0.000 & 0.500 NS \\
\hline $3 \mathrm{M}$ & 1.33 & 0.71 & 1.00 & 0.50 & 1.155 & $0.133 \mathrm{NS}$ \\
\hline $6 \mathrm{M}$ & 1.67 & 0.87 & 1.11 & 0.33 & 1.796 & $0.046^{\star}$ \\
\hline $9 \mathrm{M}$ & 2.00 & 0.71 & 1.33 & 0.71 & 2.000 & $0.031^{\star}$ \\
\hline $12 M$ & 2.11 & 0.78 & 1.56 & 0.53 & 1.768 & $0.048^{*}$ \\
\hline Fratio & \multicolumn{2}{|c|}{13.812} & \multicolumn{2}{|c|}{14.146} & & \\
\hline Probability & \multicolumn{2}{|c|}{0.0000} & \multicolumn{2}{|c|}{0.0000} & & \\
\hline LSD & \multicolumn{2}{|c|}{0.785} & \multicolumn{2}{|c|}{0.545} & & \\
\hline
\end{tabular}

2. Changes within each group:

Results of the changes by time within each group are presented in (Table IX). There was statistically significant difference between baseline records and all other intervals in both groups.

While there was no significant difference by time within each group between all other intervals $3,6,9$, and 12 months.

Table IX - Paired Comparison

\begin{tabular}{|c|c|c|}
\hline \multirow{2}{*}{ Plaque Index } & \multicolumn{2}{|c|}{ Probability } \\
\hline & Mean & StDev \\
\hline Baseline-3M & $0.002^{\star}$ & $0.001^{*}$ \\
\hline Baseline-6M & $0.001^{\star}$ & $0.0018^{\star}$ \\
\hline Baseline-9M & $0.001^{\star}$ & $0.001^{\star}$ \\
\hline Baseline-12M & $0.001^{\star}$ & $0.001^{\star}$ \\
\hline $3-6 \mathrm{M}$ & $0.821 \mathrm{NS}$ & $0.900 \mathrm{NS}$ \\
\hline $3-9 \mathrm{M}$ & $0.258 \mathrm{NS}$ & $0.571 \mathrm{NS}$ \\
\hline 3-12M & 0.136 NS & $0.118 \mathrm{NS}$ \\
\hline $6-9 M$ & $0.821 \mathrm{NS}$ & $0.844 \mathrm{NS}$ \\
\hline 6-12M & $0.631 \mathrm{NS}$ & $0.296 \mathrm{NS}$ \\
\hline $9-12 M$ & $0.900 \mathrm{NS}$ & $0.844 \mathrm{NS}$ \\
\hline
\end{tabular}

\section{B. Gingival Index (mGI)}

1. Comparison between groups:

Results of comparison between groups are presented in (Table X). There was no statistical significant difference between both groups at all follow-ups intervals.

Table $\mathbf{X}$ - One-way ANOVA comparing mean values of gingival index during the follow up period in both groups and independent student " $\mathrm{t}$ " test comparing both groups in each interval

\begin{tabular}{|c|c|c|c|c|c|c|}
\hline \multirow{2}{*}{$\begin{array}{l}\text { Gingival } \\
\text { Index }\end{array}$} & \multicolumn{2}{|c|}{ Zirconium } & \multicolumn{2}{|c|}{ PEEK } & \multirow{2}{*}{$t$} & \multirow{2}{*}{ Probability } \\
\hline & Mean & StDev & Mean & StDev & & \\
\hline Baseline & 1.00 & 0.71 & 0.89 & 0.60 & 0.359 & 0.362 \\
\hline $3 M$ & 1.44 & 0.53 & 1.11 & 0.33 & 1.604 & 0.064 \\
\hline $6 \mathrm{M}$ & 1.56 & 0.73 & 1.56 & 0.53 & 0.000 & 0.500 \\
\hline $9 M$ & 1.67 & 0.71 & 1.44 & 0.88 & 0.590 & 0.282 \\
\hline $12 \mathrm{M}$ & 1.89 & 0.93 & 1.78 & 0.67 & 0.292 & 0.387 \\
\hline Fratio & \multicolumn{2}{|c|}{1.833} & \multicolumn{2}{|c|}{2.873} & & \\
\hline Probability & \multicolumn{2}{|c|}{0.141} & \multicolumn{2}{|c|}{0.035} & & \\
\hline LSD & \multicolumn{2}{|c|}{0.834} & \multicolumn{2}{|c|}{0.717} & & \\
\hline
\end{tabular}

\section{Changes within each group:}

Results of the changes by time within each group are presented in (Table XI), There was no statistically significant difference between baseline records and all other intervals in both groups except after 12 months in the "Peek" group with no statistically significant difference between all other intervals (3, 6, 9 and 12 months).

Table XI - Paired comparison

\begin{tabular}{|c|c|c|}
\hline & \multicolumn{2}{|c|}{ Probability } \\
\hline & Zirconium & PEEK \\
\hline Baseline-3M & $0.676 \mathrm{NS}$ & $0.900 \mathrm{NS}$ \\
\hline Baseline-6M & $0.498 \mathrm{NS}$ & $0.182 \mathrm{NS}$ \\
\hline Baseline-9M & $0.315 \mathrm{NS}$ & $0.347 \mathrm{NS}$ \\
\hline Baseline-12M & $0.093 \mathrm{NS}$ & $0.035^{*}$ \\
\hline $3-6 M$ & $0.900 \mathrm{NS}$ & $0.560 \mathrm{NS}$ \\
\hline $3-9 \mathrm{M}$ & $0.900 \mathrm{NS}$ & $0.767 \mathrm{NS}$ \\
\hline $3-12 \mathrm{M}$ & $0.676 \mathrm{NS}$ & 0.182 NS \\
\hline $6-9 M$ & $0.900 \mathrm{NS}$ & $0.900 \mathrm{NS}$ \\
\hline $6-12 M$ & $0.854 \mathrm{NS}$ & 0.900 NS \\
\hline 9-12M & 0.900 NS & $0.767 \mathrm{NS}$ \\
\hline
\end{tabular}




\section{DISCUSSION}

This study was a randomized, double blinded clinical trial where randomization was carried out by using computerized sequence generation (www.randomizer.org) to eliminate the risk of selection bias of the included patients. It provided a comprehensive comparison between the Zirconium and PEEK abutment groups using various biologic and esthetic parameters. Since the main investigator performed all the procedures during this study, then, the evaluation of the outcome had to be performed by experienced evaluators who were blinded and did not know the patients belong to which group.

The increasing esthetic demand in implant dentistry is directly related to the materials, techniques and treatment procedures. The material of the implant abutment used in the esthetic area is of extreme importance for the esthetics and biomechanical features. Therefore a variety of materials consisting of gold, zirconia, alumina, lithium disilicate and polymeric materials instead of titanium for implant abutments would be highly desirable [19].

All restorations included in this study were in the esthetic zone in compliance with the patient's maximum smile. The most visible teeth in dental arch where esthetics, shade and patient satisfaction play a pivotal role for successful restoration.

An implant with a platform-switched implant was used in this study. Canullo et al. 2009 [7] claimed that the use of platform switched implant better maintained the bone levels more than platform matched implants. This was in accordance with a systematic review and meta-analysis by Annibali et al. in 2012 [20] that concluded that platform switched showed better marginal bone preservation in comparison to other platform matched implants.

The ultimate goal of the therapy is to satisfy the patient's desire to replace a lost tooth with a functional and esthetic solution. Hence, criteria for successful implant therapy should always incorporate the patient's view. If objective indices by clinicians are not correlated with the patients' esthetic perception, the practitioner may be overlooking potential treatments or materials that could better satisfy the patient's needs. In this study, the patients were presented with four simple but specific questions, and the scores of the combined answers were considered for the overall patient's satisfaction [21].

The Pink Esthetic Score (PES) is a suitable parameter for reproducible evaluation of the soft tissue around single tooth implant crowns (Furhauser et al., 2005) [2]. Moreover, Gehrke et al. [22] tested the reproducibility of the pink esthetic score, suggesting that it allowed for a more objective appraisal of the esthetic shortand long-term results of various surgical and prosthetic implant procedures. Patil Ratnadeep et al. [21] compared the PES between different abutment design and claims that esthetics around the implants depends upon several factors from anatomical and surgical point of view. Such as anatomically narrow alveolar crest, trauma, acute or chronic infection and disuse bone atrophy.

One of the key factors for the long-term success of dental implants is the maintenance of healthy soft tissues around them. A causeeffect relationship between bacterial plaque accumulation of the restoring material and the development of inflammatory changes in the soft tissues surrounding dental implants has been thought of. If bacterial accumulation is left untreated, it may lead to the progressive destruction of the tissues supporting an implant as peri-implantitis, which may compromise the implant structure and its future and ultimately lead to its failure. An implant patient must always be enrolled in a supportive postoperative therapy program that involves recall visits at regular intervals for hygiene sessions [23].

The redness and swelling of the marginal tissues, bleeding on probing (BOP), pocket formation and suppuration has been reported to result from peri-implant infections. Assessment of these clinical signs has been considered important in the diagnosis of periodontal 
diseases. Therefore, the definition of periimplant parameters based on periodontal indices such as modified gingival index is indicated. The modified gingival index was modified by Apse and associates. Indices used to assess marginal mucosal condition around oral implants [24].

Patient satisfaction score was recorded for both groups by Visual Analogue Score (VAS). The results showed statistically significant difference between both groups as the satisfaction was higher for the PEEK group than the Zirconium group. This might be related to the lower modified plaque score recorded for the PEEK group through the one-year follow up. The reason is due to the decreased degree of plaque around PEEK abutments owing to its smoother surface, that gives a more natural healthy esthetic outcome to the single implant restoration.

Skirbutis et al. in 2017 [25], stated that PEEK has a low plaque affinity, which was also backed by Najeeb et al. in 2016 [26] Additional advantage of PEEK is its high polish ability that also adds to its lower plaque affinity property [27].

Kim et al., 2015 [28] stated that zirconium abutments showed higher patient satisfaction than the use of titanium abutments. The author stated the spectrophotometer showed lower gingival color difference for the zirconium abutment than the titanium or gold-hued titanium abutment.

Contradicting to the results those found by Borzangy et al. in 2016 [3], who found there was no statistical difference between both groups comparing titanium and zirconium abutments in the anterior region. The author claimed that the self-esteem of most patients increased after crown insertion regardless the type of prosthesis used.

The Pink Esthetic Score for the PEEK group showed higher values for the PES than the zirconium group although the results showed no statistical difference between both groups. Both groups showed adequate esthetic outcome. This might be due to the presence of healthy soft tissues around the abutments, proper width of keratinized tissues, and good soft tissue morphology from having used the appropriate dimensions for the final prosthesis. The use of the same superstructure as the CAD e.max crown could also influence the PES to be similar for both groups.

Skirbutis et al. in 2017 [25], stated that PEEK has a low plaque affinity, which was also backed by Najeeb et al. in 2016 [26]. Additional advantage of PEEK is its high polish ability that also adds to its lower plaque affinity property [27].

Kim et al. [28] stated that zirconium abutments showed higher patient satisfaction than the use of titanium abutments. The author stated the spectrophotometer showed lower gingival color difference for the zirconium abutment than the titanium or gold-hued titanium abutment.

Albornoz et al. in 2014 [29], compared patient satisfaction between zirconium and titanium groups. The zirconium group demonstrated a higher esthetic outcome than the titanium group.

Contradicting to the results those found by Borzangy et al. in 2016 [3], who found there was no statistical difference between both groups comparing titanium and zirconium abutments in the anterior region. The author claimed that the self-esteem of most patients increased after crown insertion regardless the type of prosthesis used.

The Pink Esthetic Score for the PEEK group showed higher values for the PES than the zirconium group although the results showed no statistical difference between both groups. Both groups showed adequate esthetic outcome. This might be due to the presence of healthy soft tissues around the abutments, proper width of keratinized tissues, and good soft tissue morphology from having used the appropriate dimensions for the final prosthesis. The use of the same superstructure as the CAD e.max crown could also influence the PES to be similar for both groups.

These observations were in accordance with a study by Albornoz et al. in 2014 [29]. Although the zirconium group showed better esthetic outcomes, yet there was no statistical 
difference with the titanium group.

Similar findings were documented by Borzangy et al. in 2016 [3], concluding that there was no difference between both zirconium and titanium group in regards to PES. This was also agreed upon by Gallucci et al. in 2011 [30], that no difference was recorded when the dimensional changes of peri-implant soft tissue of single-implant crowns in the anterior maxilla were analyzed. The author explained the reason for the results to be affected by the mucosal thickness, which affects the peri-implant soft tissue regardless of the abutment material used. Also soft tissue handling at the time of implant placement, where a substantial amount of keratinized mucosa should ideally be preserved at the facial aspect.

On the contrary, Payer et al. in 2015 [31], showed that PES around zirconium abutments was significantly higher compared to Titanium abutments at 2-year follow up. In 2015, Linkevicius et al. [32] conducted a systematic review and meta-analysis concluding that there is a significant tendency in Zirconium abutments evoking better color response of periimplant mucosa and superior esthetic outcome measured by PES score.

Peri-implant clinical parameters were evaluated in terms of modified plaque index and modified gingival index. The modified plaque index (mPI) showed significantly lower scores for the PEEK group versus the zirconium group. This could be due to the lower degree of surface roughness exhibited by the PEEK surface in comparison to zirconium. Which is in accordance with Hahnel et al. 2015 [4] whom tested the surface roughness of PEEK, PMMA, zirconium and titanium. The results showed significantly lower surface roughness as opposed to the rest of the materials. Author suggested that PEEK has lower biofilm formation than on the conventionally applied abutment materials titanium and zirconium. Concluding that PEEK has feature favorable properties as definitive abutment material.

Contradicting to those results, Najeeb et al. in 2016 [33] stated that PEEK didn't show any difference in the degree of bacterial adhesion in comparison to PEEK and titanium.

Sailer et al. in 2009 [34], compared the plaque index for both zirconium and titanium abutments. Between both groups, zirconium had slightly higher plaque accumulations than the titanium group. The author clarified that this difference in plaque accumulation might be due to differences in emergence profile of both abutments. On the Contrary, Borzangy et al. in 2016 [3], found no difference in plaque index between both the zirconium and titanium abutments.

This study also recorded the modified gingival index (mGI) for both groups. There was no statistically significant difference between both groups in regards to the modified gingival index in a follow up period of 1 year.

The results were consistent with Borzangy et al., Zembic et al., Hosseini et al., Sailer et al. $[3,10,34,35]$ they stated that there was no difference in bleeding on probing for both groups comparing zirconium and titanium abutments. None of them found statistically significant differences at 1,3 , and 5 years follow up. By claiming that the plaque index was lower for the single implant restoration in comparison to adjacent natural teeth.

Therefore, the null hypothesis was rejected, as the PEEK group showed higher patients satisfaction with a significant difference and lower plaque index as well as opposed to the zirconium group. On the other hand the two groups showed no statistical significant difference when compared on the basis of the PES and the modified gingival index.

\section{CONCLUSIONS}

PEEK revealed to be a versatile material to replace zirconium for implant abutments, due to its lower plaque affinity and higher patient satisfaction.

\section{Clinical Implications}

- Proper tissue molding by the use of customized healing collar and a soft tissue 
impression for maximum soft tissue esthetics.

- The use of a customized abutment rather than a stock abutment for better esthetic appearance to mimic the soft tissue of the proposed extracted tooth.

- It is advised to use PEEK material as implant abutments as it showed lower plaque affinity and higher patient satisfaction.

- Current dental professionals can benefit from new developments related to novel materials that can be used as suitable abutments for optimum esthetic results.

\section{Recommendations}

A larger number of randomized controlled clinical studies with large sample sizes and longer follow-up intervals are required to establish evidence in implant dentistry regarding the validity of the relative clinical performance of PEEK and Zirconium abutments.

\section{Limitations}

- The small sample size in each group, so study findings may not be reproducible. - More clinical studies are required with prolonged follow-up periods in order to evaluate long- term esthetic clinical performance of the materials along with patient satisfaction in order to be used in different situations for better esthetic outcome.

\section{Acknowledgments}

The authors are grateful to members of evidence based committee, faculty of oral and dental medicine, Cairo university for content contributions, members of ethical committee faculty of oral and dental medicine, Cairo university for their critical review of the manuscript and the members of fixed prosthodontics department, faculty of oral and dental medicine, Cairo university for support during the development and writing of this manuscript.

\section{Funding}

This study was partially supported by the main author.

\section{Conflict of interest}

The authors have no proprietary, financial, or other personal interest of any nature or kind in any product, service, and/or company that is presented in this article.

\section{Regulatory Statement}

This study was conducted in accordance with all the provisions of the local human subject's oversight committee guidelines and policies of: Faculty of Oral and Dental Medicine, Cairo University, Ethics Committee. The approval code for this study is: $16|9| 2$.

\section{REFERENCES}

1. Albrektsson T,Zarb G, Worthington P, Eriksson AR. The long-term efficacy of currently used dental implants: a review and proposed criteria of success. Int J Oral Maxillofac Implants. 1986 Summer;1(1):11-25. PMID: 3527955.

2. Fürhauser R, Florescu D, Benesch T, Haas R, Mailath G, Watzek G. Evaluation of soft tissue around single-tooth implant crowns: the pink esthetic score. Clin Oral Implants Res. 2005 Dec;16(6):639-44. doi:10.1111/.16000501.2005.01193.x. PMID: 16307569.

3. Borzangy S. A Comparison of Zirconia CAD / CAM to Conventionally Fabricated Single Implant Restorations in the Esthetic Zone. [Doctoral Dissertation]. Harvard School of Dental Medicine. 2015.

4. Hahnel S, Wieser A, Lang R, Rosentritt M. Biofilm formation on the surface of modern implant abutment materials. Clin Oral Implants Res. 2015 Nov;26(11):1297-301. doi: 10.1111/cri.12454. Epub 2014 Jul 24. PMID: 25060652.

5. Misch CE. Dental Implant Prosthetic. 1st ed. St Louis, MO: Mosby. 2005

6. Hansson S, Halldin A. Alveolar ridge resorption after tooth extraction: A consequence of a fundamental principle of bone physiology. J Dent Biomech. 2012;3:1758736012456543. doi: 10.1177/1758736012456543. Epub 2012 Aug 16. PMID:22924065; PMCID: PMC3425398.

7. Burns J, Palmer R, Howe L, Wilson R. Accuracy of open tray implant impressions: an in vitro comparison of stock versus custom trays. J Prosthet Dent. 2003 Mar;89(3):250-5. doi: 10.1067/mpr.2003.38. PMID: 12644799.

8. Chaiyabutr Y, Kois JC, Lebeau D, Nunokawa G. Effect of abutment tooth color, cement color, and ceramic thickness on the resulting optical color of a CAD/ CAM glass-ceramic lithium disilicate-reinforced crown. J Prosthet Dent. 2011 Feb;105(2):83-90. doi: 10.1016/S0022-3913(11)60004-8. PMID:21262405.

9. Li Q, YuH, Wang YN. In vivo spectroradiometric evaluation of colour matching errors among five shade guides. J Oral Rehabil. 2009 Jan;36(1):6570. doi:10.1111/.j.1365-2842.2008.01894.x. Epub 2008 0ct22. PMID: 18976272.

10. Hosseini M, Worsaae N, Schiodt M, Gotfredsen K. A 1-year randomised controlled trial comparing zirconia versus metal-ceramic implant supported single-tooth restorations. Eur J Oral Implantol. 2011 Winter;4(4):347-61. PMID: 22282731 .

11. Palacci P,Nowzari H. Soft tissue enhancement around dental implants. Periodontol 2000. 2008;47:113-32. doi: 10.1111/j.1600-0757.2008.00256.x. PMID: 18412577. 
12. Hermann JS, Buser D, Schenk RK, Higginbottom FL, Cochran DL. Biologic width around titanium implants. A physiologically formed and stable dimension over time. Clin Oral Implants Res. 2000 Feb;11(1):1-11. doi: 10.1034/j.1600-0501.2000.011001001.X. PMID: 11168188

13. Levine RA, Huynh-Ba G, Cochran DL. Soft tissue augmentation procedures for mucogingival defects in esthetic sites. Int J Oral Maxillofac Implants. 2014;29 Suppl:155-85. doi:10.11607/jomi.2014suppl.g3.2. PMID: 24660197.

14. Stawarczyk B, Beuer F, Wimmer T, Jahn D, Sener B, Roos M, Schmidlin PR Polyetheretherketone-a suitable material for fixed dental prostheses? J Biomed Mater Res B Appl Biomater.2013 0ct;101(7):1209-16. doi:10.1002/ jbm.b.32932. Epub 2013 Apr 6. PMID: 23564476.

15. Tymstra N, Raghoebar GM, Vissink A, Meijer HJ. Maxillary anterior and mandibular posterior residual ridge resorption in patients wearing a mandibular implant-retained overdenture. J Oral Rehabil. 2011 Jul;38(7):50916. doi: 10.1111/.j1365-2842.2010.02180.x. Epub 2010 Nov 24. PMID: 21092056.

16. Ishikawa-Nagai S, Da Silva JD, Weber HP, Park SE. Optical phenomenon of peri-implant soft tissue. Part Il. Preferred implant neck color to improve soft tissue esthetics. Clin Oral Implants Res. 2007 0ct;18(5):575-80. doi: 10.1111/.j.1600-0501.2007.01390.x. Epub 2007 Jul 26. PMID: 17655714.

17. Welander $\mathrm{M}, \mathrm{Abrahamsson} \mathrm{I}$, Berglundh $\mathrm{T}$. The mucosal barrier at implant abutments of different materials. Clin Oral Implants Res. 2008 Jul;19(7):63541. doi:10.1111/.j.1600-0501.2008.01543.x. Epub 2008 May 19. PMID: 18492075.

18. Davidowitz G, Kotick PG. The use of CAD/CAM in dentistry. Dent Clin North Am. 2011 Jul;;5(3):559-70, ix. doi:10.1016/j.cden.2011.02.011. PMID:21726690.

19. Sailer I,Zembic A, Jung RE, Siegenthaler D, Holderegger C, Hämmerle $\mathrm{CH}$. Randomized controlled clinical trial of customized zirconia and titanium implant abutments for canine and posterior single-tooth implant reconstructions: preliminary results at 1 year of function. Clin Oral Implants Res. 2009 Mar;20(3):219-25. doi:10.1111/.11600-0501.2008.01636.x.PMID: 19397632.

20. Annibali S, Bignozzi I, Cristalli MP, Graziani F, La Monaca G, Polimeni A. Peri-implant marginal bone level: a systematic review and meta-analysis of studies comparing platform switching versus conventionally restored implants. J Clin Periodontol. 2012 Nov;39(11):1097-113. doi: 10.1111/1.1600051X.2012.01930.x. Epub 2012 Aug 29. PMID: 22931292

21. Patil R, Gresnigt MMM, Mahesh K, Dilbaghi A, Cune MS. Esthetic Evaluation of Anterior Single-Tooth Implants with Different Abutment Designs-Patients' Satisfaction Compared to Dentists' Observations. J Prosthodont. 2017 Jul;26(5):395-398. doi: 10.1111/jopr.12423. Epub 2016 Jan 15. PMID: 26773736

22. Gehrke P,Lobert M, Dhom G. Reproducibility of the pink esthetic score-rating soft tissue esthetics around single-implant restorations with regard to dental observer specialization. J Esthet Restor Dent. 2008;20(6):375-84; discussion 385. doi:10.1111/.j.1708-8240.2008.00212.x. PMID: 19120783.

23. Pathak A, Goel K, Shakya V, Tiwari AK. Periodontal parameters around implants and natural teeth. Natl J Maxillofac Surg. 2006;7(1):52-55. doi: 10.4103/0975-5950.196130
24. Salvi GE, Lang NP. Diagnostic parameters for monitoring peri-implant conditions. Int J Oral Maxillofac Implants. 2004;19 Suppl:116-27.PMID: 15635952.

25. Skirbutis G, Dzingutė A, Masiliūnaitė V, Šulcaitė G, Žilinskas J. A review of PEEK polymer's properties and its use in prosthodontics. Stomatologija. 2017;19(1):19-23. PMID: 29243680.

26. Mombelli A, van Oosten MA, Schurch E Jr, Land NP. The microbiota associated with successful or failing osseointegrated titanium implants. Oral Microbiol Immunol. 1987 Dec;2(4):145-51. doi: 10.1111//.1399-302x.1987. tb00298.x. PMID:3507627.

27. Zoidis P,Papathanasiou I, Polyzois G. The Use of a Modified Poly-Ether-EtherKetone (PEEK) as an Alternative Framework Material for Removable Dental Prostheses. A Clinical Report. J Prosthodont. 2016 0ct;25(7):580-584. doi: 10.1111/jopr.12325. Epub 2015 Jul 27.PMID: 26216668.

28. Kim D, Lim B, Kim C. Relationship between patient satisfaction with medical doctors and the use of traditional Korean medicine in Korea. BMC Complement Altern Med. 2015 0ct 14;15:355. doi: 10.1186/s12906-0150879-x. PMID:26467297;PMCID: PMC4604758.

29. Carrillo de Albornoz A, Vignoletti F, Ferrantino L, Cárdenas E, De Sanctis M, Sanz M. A randomized trial on the aesthetic outcomes of implant-supported restorations with zirconia or titanium abutments. J Clin Periodontol. 2014 Dec;41(12):1161-9. doi: 10.1111/jcpe.12312. Epub 2014 Nov 21. PMID: 25244317.

30. Gallucci GO, Grütter L, Nedir R, Bischof M, Belser UC. Esthetic outcomes with porcelain-fused-to-ceramic and all-ceramic single-implant crowns: a randomized clinical trial. Clin Oral Implants Res. 2011 Jan;22(1):62-9. doi: 10.1111/j.1600-0501.2010.01997.x. Epub 2010 Sep 24. PMID: 21158931.

31. Payer M, Heschl A, Koller M, ArnetzI G, Lorenzoni M, Jakse N. All-ceramic restoration of zirconia two-piece implants--a randomized controlled clinica trial. Clin Oral Implants Res. 2015 Apr;26(4):371-376. doi: 10.1111/clr.12342. Epub 2014 Feb 6. PMID: 24502675

32. Linkevicius T, Puisys A, Steigmann M, Vindasiute E, Linkeviciene L. Influence of Vertical Soft Tissue Thickness on Crestal Bone Changes Around Implants with Platform Switching: A Comparative Clinical Study. Clin Implant Dent Relat Res. 2015 Dec;17(6):1228-36. doi:10.111//cid.12222. Epub 2014 Mar 28. PMID: 24673875

33. Najeeb S, Zafar MS, Khurshid Z, Siddiqui F. Applications of polyetheretherketone (PEEK) in oral implantology and prosthodontics. J ProsthodontRes. 2016 Jan;60(1):12-9. doi:10.1016/j.jpor.2015.10.001.PMID: 26520679.

34. Sailer I, Sailer T, Stawarczyk B, Jung RE, Hämmerle CH. In vitro study of the influence of the type of connection on the fracture load of zirconia abutments with internal and external implant-abutment connections. Int $\mathrm{J}$ Oral Maxillofac Implants. 2009 Sep-0ct;24(5):850-8. PMID: 19865625.

35. Zembic A, Sailer I, Jung RE, Hämmerle CH. Randomized-controlled clinical trial of customized zirconia and titanium implant abutments for single-tooth implants in canine and posterior regions: 3 -year results. Clin Oral Implants Res. 2009 Aug;20(8):802-8. doi:10.1111/.1600-0501.2009.01717.x. Epub 2009 May 26. PMID: 19486077.

\section{Mostafa M El-Shabrawy (Corresponding address)}

Lecturer Assistant, Fixed Prosthodontics, Faculty of Oral and Dental Medicine, Egyptian Russian University, Badr City, Cairo-Suez road, Postal Code: 11829, Cairo, Egypt. Email: mostafa.elshabrawy@dentistry.cu.edu.eg

Date submitted: 2020 Sep 15 Accept submission: 2020 Nov 17 